\title{
Activity of isolated specific bacteriophage in treatment of chronic osteomyelitis induced by multiple drug resistance Pseudomonas aeruginosa in Rabbits
}

\section{Sarhan Rashid Sarhan}

Department of Physiology and Pharmacology, College of Veterinary Medicine,

Wasit University, Iraq.

E-mail: srashid@uowasit.edu.iq

Received: $16 / 7 / 2017$

Accepted: 26/8/2017

\section{Summary}

This study was conducted to find out the possibility of using the Pseudomonas aeruginosa specific-bacteriophage as an alternative to antibiotics in treatment of chronic osteomyelitis in rabbits by injection of Pseudomonas aeruginosa suspension in tibia. The current study included an isolation of bacteriophage from sewage water by using agar overlay method and also an isolation of the bacteria from patients suffering from post-traumatic bone infection. The second experiment was in-vivo evaluation of phage activity in treatment of chronic osteomyelitis in rabbits. All animals of infected groups with Pseudomonas aeruginosa before treatment exhibited histopathological changes after 35 days of infection, the infected groups showed chronic osteomyelitis represented by sever chronic inflammatory cells infiltrates mainly lymphocytes, and macrophages and hemorrhage between bone trabeculae, also some sections showed extensive fibrosis in the marrow spaces. The treated group with $P$. aeruginosa specific - bacteriophage $\left(1.5 \times 10^{7}\right)$ PFU/ml for 10 days showed early repair elucidated by presence whorls of chondrocytes, and also the presence of multiple osteoblasts indicated bone formations. Also the presence of extensive fibrosis in the marrow space with present of osteoblasts indicated bone formations and repair.

Keywords: Chronic osteomyelitis, Pseudomonas aeruginosa, Bacteriophage, Rabbits.

\section{Introduction}

Osteomyelitis is an inflammatory process of the entire bone including the cortex and the periosteum, accompanied by bone destruction and caused by an infecting organism (1). Osteomyelitis is a disease in transition, with ongoing changes in predisposing factors, causative organisms and treatment (2). It affects both adults and children. Patients with certain conditions such as intravenous drug users like heroin, cocaine, methamphetamines and opiates, decubitus ulcers, surgery, trauma, immunosuppression, immune diseases (i.e. rheumatoid arthritis), diabetes mellitus, smoking, malnutrition, malignancy, extremes of age, chronic hypoxia, and renal or hepatic failure are at increased risk of osteomyelitis (3). Prognosis of osteomyelitis is largely dependent on the mechanism of infection, the virulence of the infecting organism, the immune status and health status of the patient (4). The mortality rate is low unless associated with sepsis or when a serious medical condition is present (5). Untreated or due to treatment failure, the infection can progress to a more chronic phase. Chronic osteomyelitis is defined as bone infection in the presence of osteonecrosis. It is associated with formation of a large area of devascularized dead bone, a sequestrum (6). The most common pathogens responsible for osteomyelitis in humans are Staphylococcus species, followed by Enterobacteriaceae and Pseudomonas species (7). Haemolytic streptococci are also responsible for bone infection (8). Gramnegative bacteria Pseudomonas aeruginosa and Enterobacteriaceae have grown in important causative agents due to the increasing number of orthopedic surgery with the use of implants and, especially, the rising number of high-energy traumas associated with open fractures, as a consequence of traffic accidents and war injuries (9). There are three classes of antibiotic resistance in $P$. Aeruginosa: Intrinsic resistance, acquired resistance and genetic resistance (10). Another part of the resistance appears to be caused by two recently discovered multidrug efflux systems (11). In some cases, enzymes that specifically inactivate antibiotics lead to antibiotic resistance. Therefore, exploring alternative approaches to develop antibacterial products is also a worthwhile task, and reexamining the potential of promising older 
methods might be of value. One of the possible replacements for antibiotics is the use of bacteriophages or simply phages as antimicrobial agents (12). Phage therapy involves the use of lytic phages for the treatment of bacterial infections, especially those caused by antibiotic resistant bacteria. In general, there are two major types of phages, lytic and lysogenic. Only the lytic phages (also known as virulent phages) are a good choice for developing therapeutic phage preparations (13). The bactericidal ability of phages has been used to treat human infections for years as a complement or alternative to antibiotic therapy (14). The investment of phages as a pragmatic approach in the control of pathogens has attracted considerable interest (15). Therefore, the present study was aimed to find out the possibility of using the specific- $P$. aeruginosa bacteriophage as an alternative treatment of chronic osteomyelitis in rabbits.

\section{Materials and Methods}

Eighty five sample of pus were collected from patient hospitalized in Al-Zahra teaching hospital in Wasit province, they were suffering from post-traumatic bone infection. Pus was collected by the use of sterile syringes and promptly taken to the laboratory and processed. Methods used for isolation and identification of Pseudomonas aeruginosa were Gram stain (BDH, England), Pyocianin on cetrimide (Himedia, India), Indole production (Himedia, India), VogesProskauer, Citrate utilization, Oxidase and catalase tests (Himedia, India) (16). Pseudomonas aeruginosa isolates were tested for sensitivity to 10 commonly used antibiotics (Bioanalyse, Turkey) by using disk diffusion methods (17). Lawn culture was done on Muller-Hinton agar (Oxoid, England). Plates were incubated (Binder, Germany) at $37^{\circ} \mathrm{C}$ for $18 \mathrm{hr}$. and zone diameters were measured. Results were interpreted according to clinical laboratory Standards Institute (2012) (18).

Bacteriophages isolation and propagation: This method was adapted from (19 and 20). Two hundred $(\mathrm{ml})$ raw sewage collected from hospital sewages was measured by graduated cylinder. The sample was centrifuged (MPW, Poland) at $5000 \mathrm{rpm}$ for $15 \mathrm{~min}$., the supernatant was filtered through $0.22 \mu \mathrm{m}$
Millipore filter (Gema medical S.L., Spain) One hundred $(\mu \mathrm{l})$ of overnight Pseudomonas aerugenosa were cultured on Luria broth (Hi Media, India) pipetted in a sterile test tube. This was followed by the addition of $3 \mathrm{ml}$ of sewage sample containing-specific phage added to the bacterial culture. Then, $2 \mathrm{ml}$, equal volume of Tryptic soy broth (Hi Media, India) and $2 \mathrm{ml}$ of Lambda buffer (Clontech, US, CAT no. 634144) were added to the contents as well. Then, the contents were incubated for 24 hours at $37^{\circ} \mathrm{C}$ with shaking. On the following day, $5 \mathrm{ml}$ of the contents (phage and pseudomonas aeruginosa) was distributed into a sterile $15 \mathrm{ml}$ test tube, centrifuged at $1000 \mathrm{rpm}$ for $3 \mathrm{~min}$. at room temperature. One $\mathrm{ml}$ of supernatant was transferred to $1.5 \mathrm{ml}$ Eppendorf tube. Then, $0.1 \%$ chloroform (Kundan group, India) was added to the supernatant with gentle shaking for $10 \mathrm{~min}$. at room temperature to lyse the remaining bacteria. Centrifugation of the Eppendorf tubes using regular centrifuge at $1000 \mathrm{rpm}$ for $3 \mathrm{~min}$; the supernatant was transferred into new Eppendorf tube and equal volume of lambda buffer was added.

Phage infectivity test by using spot test technique: One $\mathrm{ml}$ of overnight culture of bacterial broth was poured on to nutrient agar (Oxoid, England) plate in order to make bacterial lawn. After 30 min., the lawn should have been dried. Ten $(\mu l)$ of phage suspension were dropped on to the surface of the bacterial lawn and were allowed to dry before incubating at $37^{\circ} \mathrm{C}$ for $24 \mathrm{hr}$. A lytic and specific phage can be discovered for the target bacteria if zone of lysis was developed at the spot where the phage suspension was applied (21).

Phage titration by using plaque assay: Ten serial dilutions $\left(10^{-1}\right.$ to $\left.10^{-9}\right)$ were made with Lambda buffer for the phage stock solutions by taking $100 \mu \mathrm{l}$ of the phage solution into 900 $\mu \mathrm{l}$ of lambda buffer. One hundred (100) $\mu$ l of each dilution were transferred for each phage stock solution into $15 \mathrm{ml}$ volume sterile plastic container containing $100 \mu \mathrm{l}$ of $10^{9} \mathrm{CFU} / \mathrm{ml}$ cultures of targeted bacteria. The contents were mixed thoroughly and transferred to the $2.5 \mathrm{ml}$ of top layer agar (soft agar or semisolid agar of concentration $0.5 \%$ cooled at $45^{\circ} \mathrm{C}$ ). Immediately, the resulting mixture was 
poured over nutrient agar plates (bottom agar). Plates were incubated at $37^{\circ} \mathrm{C}$ for $24 \mathrm{hrs}$. This procedure, called overlay methods, was also done with other serial dilutions of bacterio -phage. Phage titer was calculated for every dilution and it was found out the dilution factor used in-vivo experiment (22). The phage titer was calculated by using the following formula: Phage titer $=$ Number of plaques per plate $\times 100 \times$ dilution factor. Accordingly, the clearest and largest plaques were selected.

Thirty healthy male rabbits (local breed rabbits), were divided equally into 3 groups. Their age extended between 12-14 weeks, and animals weighing between $1.5-2 \mathrm{~kg}$. Rabbits were put in standard rabbits cage. Experimental animals were fed with commercial lab animals pellets and tap water was available freely. Room temperature was maintained at $20-25^{\circ} \mathrm{C}$. Room air was changed constantly by utilizing ventilation vacuum. Litter of the cages was changed daily. In each group (treatment began immediately after chronic osteomyelitis recognized): Group A, positive control group (infected with $P$. aeruginosa and not treated). Group B, negative control group (neither infected nor treated). Group $\mathrm{C}$, infected with $P$. aeruginosa and treated with $P$. aeruginosa - specific bacteriophage intra-muscularly with $1.5 \times 10^{7}$ $\mathrm{PFU} / \mathrm{ml}$ once daily for 10 days. After one week of adaptation period, Ketamine (Fabrique par: KEPRO, Netherland) $50 \mathrm{mg} / \mathrm{kg}$ body weight and Xylazine (VMD, Belgium) 4 $\mathrm{mg} / \mathrm{kg}$ body weight were given intramuscular to anesthetized rabbits (23). Right hind limb was prepared surgically from the metatarsus to the stifle joint.

About $(2 \mathrm{~cm})$ surgical skin incision was made at the Cranio-medial site of the tibia bone of rabbit, subcutaneous structures were pushed to a side to uncover tibia bone. Dental drill (Sony, Japan) was used to make a hole (2 $\mathrm{mm}$ ), then $0.1 \mathrm{ml}$ of $P$. aeruginosa suspension was inoculated intramedully. The challenge dose that induced infection was $2 \times 10^{8} \mathrm{cfu} / \mathrm{ml}$ of bacterial suspension after pilot study, then the hole was closed with sterile bone-wax (AESCULAP, Germany), subcutaneous fascia closed by simple continuous using chromic catgut 2/0 USP. Simple interrupted stitches were used to close skin using silk suture $(2 / 0)$ (GREETMED, China). The animals were followed up clinically for signs of inflammation and for any pathological changes in the bone especially presence of sequestrum (a piece of dead bone that has become separated during the process of necrosis from normal or sound bone indicate of chronic osteomyelitis (24). Re-isolation of bacteria was performed to the scarified animals of infected and treated groups. Bone marrow was swabbed with sterile cotton-tipped applicators and then streaked onto plates of Cetrimide agar (Himedia, India) (25).

The dissected specimens of tibia from scarified animals were taken after 7 days, 35 days after induceding infection to monitor the presence of osteomyelitis and 10 days after treatment. Also another specimen was taken after 10 days of stopping treatment. Specimens were immediately fixed in $10 \%$ formalin (Merck, Germany); after the fixation, the specimens were washed with saline for 1-2 hrs and transferred to following steps: decalcification, dehydration, cleaning, impregnation with paraffin wax (Triveni chemicals, India), blocking, sectioning and staining with Haematoxylin and Eosin $(\mathrm{H}$ and E) stain (BioLab, India) (26).

Data were analyzed statistically using the Microsoft Program, SAS (Statistical Analysis System - version 9.1). Statistical analysis of data was performed on the basis of Two-Way Analysis of Variance (ANOVA) using a significant level of $(\mathrm{P}<0.05)$ and using least significant differences (LSD). Post hoc test was performed to assess significant difference among means. Also using t-test and Chisquare to identify the significance between different percentages (27).

\section{Results and Discussion}

According to microscopic characteristics, cultural and biochemical tests showed that a total of 85 pus samples which were collected from patients suffering from post-traumatic bone infection, 30 samples, showed positive results for the presence of $P$. aeruginosa. Results summarized in (Table, 1 and 2) and (Fig. 1). 


\begin{tabular}{cccccccc}
\hline \multicolumn{7}{l}{ Table, 1: Biochemical and cultural characteristics for identification of $\boldsymbol{P}$. aeruginosa. } & \\
\hline Characteristics & $\begin{array}{c}\text { Gram } \\
\text { stain }\end{array}$ & $\begin{array}{c}\text { Pyocianin on } \\
\text { cetrimide agar }\end{array}$ & $\begin{array}{c}\text { Indole } \\
\text { production }\end{array}$ & $\begin{array}{c}\text { Voges- } \\
\text { Proskauer }\end{array}$ & $\begin{array}{c}\text { Citrate } \\
\text { utilization }\end{array}$ & $\begin{array}{c}\text { Oxidase } \\
\text { test }\end{array}$ & $\begin{array}{c}\text { Catalase } \\
\text { test }\end{array}$ \\
\hline Results & Negative & Positive & Negative & Negative & Positive & Positive & Positive \\
\hline
\end{tabular}

Table, 2: Prevalence of $P$. aeruginosa from the collected samples.

\begin{tabular}{|c|c|c|}
\hline Bacteria & No. of samples & Percentage \% \\
\hline $\begin{array}{c}\text { Pseudomonas aeruginosa } \\
\text { Other } \\
\text { Total }\end{array}$ & $\begin{array}{l}30 \\
55 \\
85\end{array}$ & $\begin{array}{l}35.29 \% \\
64.70 \% \\
100 \%\end{array}$ \\
\hline $\begin{array}{l}\text { t-value }=2.837, \text { Degree of fre } \\
\text { Two-tailed probability }=0.005 \\
\text { one-sample t-test between pro } \\
\text { determine whether there was } \\
\text { percents. The } t \text {-statistic was } \\
\text { level, } t(84)=2.837, p=.0 .0057 \text {. } \\
\text { difference was significant. }\end{array}$ & $\begin{array}{l}\text { eedom }=84 \\
7 \\
\text { pportions was pe } \\
\text { a significant dif } \\
\text { ignificant at the } \\
\text { Therefore, concl }\end{array}$ & $\begin{array}{l}\text { med to } \\
\text { ace between the } \\
\text { critical alpha } \\
\text { that the }\end{array}$ \\
\hline
\end{tabular}

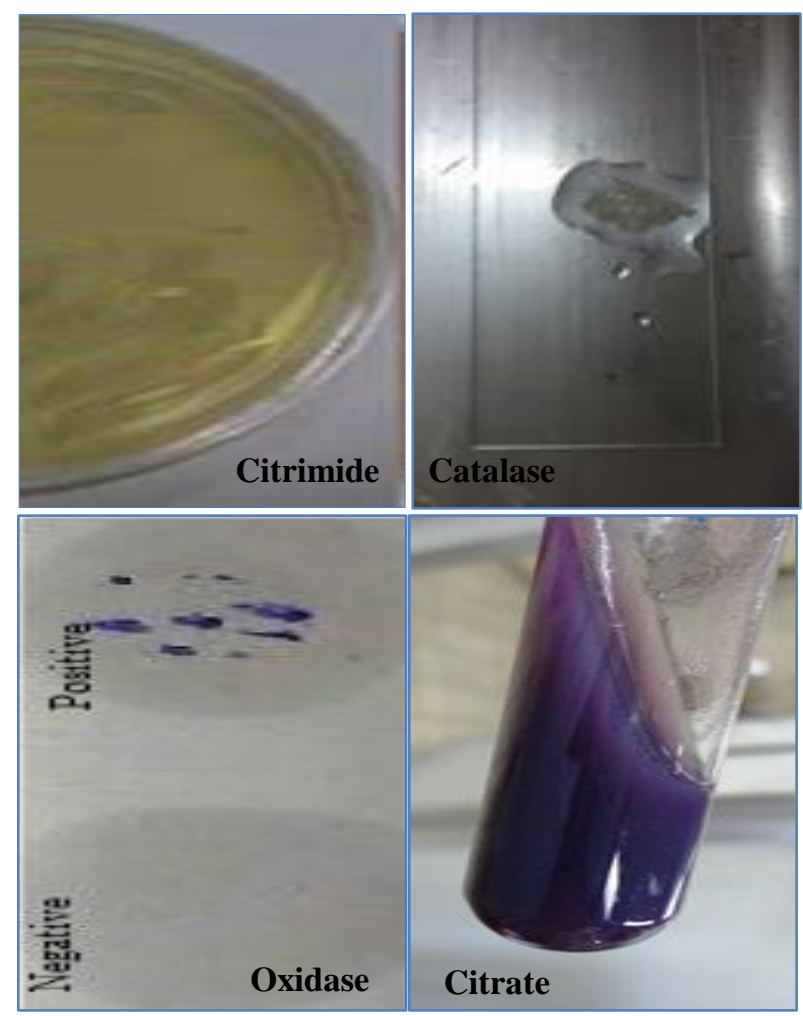

Figure, 1: positive biochemical tests for $P$. aeruginosa.

Out of the 85 specimens, only 30 (35.29\%) isolates belonged to $P$. aeruginosa, while other $55(64.70 \%)$ isolates represented other bacterial genera. Results showed a relatively high percentage. The frequency of $P$. aeruginosa may be explained by many factors, excessive antimicrobial use is a major factor that contributes to an increased frequency of multi-drug-resistant $P$. aeruginosa (28). The endemicity of multidrug resistance (MDR) P. aeruginosa in the hospital is related to various mechanisms, including de novo emergence of resistance in previously susceptible isolates, clusters secondary to patient-to-patient transmission (29). Also it is regarded as an opportunistic pathogen or may be due to factors associated with the acquisition of nosocomial pathogens in patients with recurrent or long-term hospitalization, complicating illnesses (30). In this research, the prevalence of $P$. aeruginosa isolates from bone infection was (35.29\%), this level is relatively high when compared with other studies with lower prevalence level, in India (31), reported a level of $(20.3 \%)$, while $(30 \%)$ was reported in a study conducted in Pakistan (32), and (18.25) in Egypt (33). However, these differences in prevalence were due to many variables that influence the outcome of results such as, clinical specimens received for examination, studied population, type of hospitals and geographical locations (31). Also another study done in Iraq showed that $P$. aeruginosa were most common and was (44.4\%) (44).

The results of antibiotic sensitivity test revealed that all of the tested isolates were resistant to more than five antibiotics which were designated as MDR bacteria. The antimicrobial potency of selected antibiotics against the Pseudomonas is summarized in (Table, 3). The present study showed that most isolates were resistant to the tested antibiotics. Antibiotic susceptibility test of these isolates was performed, and the results showed that all Pseudomonas isolates (100\%) were resistant to Cefotaxime, Gentamicin and Oxacillin, followed by Amikacin (96.6\%), Ceftazidime (93.3\%), Ciprofloxacin (86.6\%), Carbenicilline (80\%), Chloramphenicol (60\%), Imipenem (56.6\%), Ticarcilline (46.6\%). A major problem in $P$. aeruginosa infection is the resistance to relatively high levels of most antibiotics in use (34). Extensive use of the antimicrobial, in particular ciprofloxacin, led to an increasing incidence of ciprofloxacinresistant isolates (35). Whereas in 1984 almost $(100 \%)$ of $P$. aeruginosa isolated in the USA, Europe and Japan were susceptible to ciprofloxacin (36). The current study showed that ciprofloxacin resistance was $(86.6 \%)$. This 
study is in agreement with a study which found that $P$. aeruginosa isolated from patients demonstrated resistance to Ampicillin, Gentamicin (37). However, it disagreed with another study which observed that all $P$. aeruginosa isolates were resistant to Ampicillin, Cephalexin and Nalidixic acid while they were sensitive to Ciprofloxacin and Tobramycin (30). It seems that the major causes of resistances emergent an extensive use of the antibiotics, wrong schedule and dosing. Particularly due to the combination of the following mechanisms: Betalactamase production, a strong barrier to diffusion at the outer bacterial membrane and bacterial efflux. Selective pressure of antimicrobial drugs has an important impact on the development of bacterial resistance (38).

Table, 3: P. aeruginosa susceptibility to ten antibiotics.

\begin{tabular}{ccccc}
\hline \multirow{2}{*}{ Bacteria } & \multicolumn{3}{c}{ Pseudomonas aeruginosa $\mathrm{n}=(30)$} \\
\cline { 2 - 5 } & \multicolumn{3}{c}{ R } & \multicolumn{3}{c}{ S } \\
No & Ration & No & Ration \\
Antibiotic discs & & & & \\
Ticarcilline (TIC75) & $\mathbf{1 4}$ & $\mathbf{4 6 . 6 \%}$ & $\mathbf{1 6}$ & $\mathbf{5 3 . 4 \%}$ \\
Carbenicilline (CAR100) & $\mathbf{2 4}$ & $\mathbf{8 0 \%}$ & $\mathbf{6}$ & $\mathbf{2 0 \%}$ \\
Cefotaxime (CTX5) & $\mathbf{3 0}$ & $\mathbf{1 0 0 \%}$ & $\mathbf{0}$ & $\mathbf{0 \%}$ \\
Ceftazidime (CAZ30) & $\mathbf{2 8}$ & $\mathbf{9 3 . 3 \%}$ & $\mathbf{2}$ & $\mathbf{6 . 7 \%}$ \\
Amikacin (AK30) & $\mathbf{2 9}$ & $\mathbf{9 6 . 6 \%}$ & $\mathbf{1}$ & $\mathbf{3 . 4 \%}$ \\
Gentamicin (GM10) & $\mathbf{3 0}$ & $\mathbf{1 0 0 \%}$ & $\mathbf{0}$ & $\mathbf{0 \%}$ \\
Ciprofloxacin (CIP5) & $\mathbf{2 6}$ & $\mathbf{8 6 . 6 \%}$ & $\mathbf{4}$ & $\mathbf{1 3 . 4 \%}$ \\
Imipenem (IPM10) & $\mathbf{1 7}$ & $\mathbf{5 6 . 6 \%}$ & $\mathbf{1 3}$ & $\mathbf{4 3 . 4 \%}$ \\
Chloramphenicol (C30) & $\mathbf{1 8}$ & $\mathbf{6 0 \%}$ & $\mathbf{1 2}$ & $\mathbf{4 0 \%}$ \\
Oxacillin (OX1) & $\mathbf{3 0}$ & $\mathbf{1 0 0 \%}$ & $\mathbf{0}$ & $\mathbf{0 \%}$ \\
\hline
\end{tabular}

Chi-square value $=x 2=75.4$, there is significant $(P<0.05)$ differences among the effect of different antibiotics.

Phage isolation and titration: Phage were able to lyse bacteria and form plaques ranged from 3-4 mm. Infection of $P$. aeruginosa by phage exhibited clear and circle plaques with irregular margin on the surface agar as in (Table, 4). Isolation of one type of lytic phages against $P$. aeruginosa host bacterium from sewage illustrates that human extra is a rich repertoire of this bacterium as well as anti Pseudomonas phages. Sewage water was observed to be the best environmental source to get lytic phages with aggressive infective qualities; this might be attributed to the fact that phages from sewage tolerate hard conditions in the sewage; thus, these phages show high degree of lysis with high tolerance to harsh physical environment. This is in agreement with (39). The results clearly showed that our virulent phage for $P$. aeruginosa was highly specific. Calculation of phage titer by using series of dilutions using double layer technique and the p.f.u. for each dilution summarized in (Table, 5). Dilution factor that gave the best countable number of plaques was $\left(10^{5}\right)$; this dilution factor was then used for in vivo experiment and the $\mathrm{pfu} / \mathrm{ml}$ was $\left(1.5 \times 10^{7}\right)$.

Table, 4: Plaques Characteristics of $\boldsymbol{P}$. aeruginosa phage.

\begin{tabular}{|c|c|c|c|c|}
\hline \multirow[t]{2}{*}{$\begin{array}{c}\text { Plaques } \\
\text { characteristics }\end{array}$} & clarity & $\begin{array}{l}\text { Size } \\
(\mathrm{mm})\end{array}$ & shape & $\begin{array}{c}\text { Margin } \\
\text { cut }\end{array}$ \\
\hline & Clear & $3-4$ & Circle & Irregular \\
\hline \multicolumn{5}{|l|}{$\mathrm{N}=10$} \\
\hline \multicolumn{5}{|l|}{$\begin{array}{l}\text { Table, } 5 \\
\text { titer. }\end{array}$} \\
\hline $\begin{array}{l}\text { Plaque } 420410 \\
\text { / plate }\end{array}$ & $390 \quad 330$ & 260 & $220 \quad 160$ & $110 \quad 50$ \\
\hline $\begin{array}{ccc}\text { Phage } & \mathbf{4 . 2} & \mathbf{4 . 1} \\
\text { titer } & \times \mathbf{1 0}^{4} & \times \mathbf{1 0}^{5} \\
\text { pfu/ml }\end{array}$ & $\begin{array}{cc}3.9 & 3.3 \\
\times 10^{6} & \times 10^{7}\end{array}$ & $\begin{array}{r}2.6 \\
\times 10^{8}\end{array}$ & $\begin{array}{cc}2.2 & 1.6 \\
\times 10^{9} & \times 10^{10}\end{array}$ & $\begin{array}{cc}1.1 & 0.5 \\
\times 10^{11} & \times 10^{12}\end{array}$ \\
\hline
\end{tabular}

Re-isolation of bacteria: A high viability of tibial bacterial count (cfu/gm) from infected groups (A and $\mathrm{C}$ ) revealed positive cultures for $P$. aeruginosa and there was no significance differences between these group at a mean $\log _{10}$ concentration of $(8.15 \pm 0.05) \mathrm{cfu} / \mathrm{g}$ and (8.55 \pm 0.04$)$ after 35 days of inducing infection for group $\mathrm{A}$ and $\mathrm{C}$, respectively. While the average bacterial concentration of group C (treated with $P$ aeruginosa-specific bacteriophage intramuscularly with $1.5 \times 107$ $\mathrm{PFU} / \mathrm{ml}$ once daily for 10 days) was $(0.0 \pm 0.0)$ and of group A bacterial count remained high $(7.33 \pm 0.03)$ after ten days of therapy in comparison with negative group (group B) which showed no bacterial growth. The results showed a high significance between groups after treatment. After another 10 days of stopping treatment, there was a bacterial count in the samples of group A compared with group $\mathrm{C}$ and $\mathrm{B}$. Bacterial eradication was accompanied by a clinical and histopathological findings. Result summarized as $+/$ - in the following (Table, 6).

Histophathological section of bone tissues in control group (normal) showed normal histological architecture, represented by periosteum, Osteocytes, Haversian canal, marrow cavity and endosteum, (Fig. 2). 


\begin{tabular}{|c|c|c|c|}
\hline $\begin{array}{l}\text { Periods } \\
\text { Groups }\end{array}$ & $\begin{array}{l}\text { After inducing } \\
\text { infection } \\
\text { (35 days) }\end{array}$ & $\begin{array}{c}\text { After } 10 \\
\text { days of } \\
\text { treatment }\end{array}$ & $\begin{array}{l}\text { After another } 10 \\
\text { days of stopping } \\
\text { treatment }\end{array}$ \\
\hline Group A & $8.15 \pm 0.05$ & $7.33 \pm 0.03$ & $7.05 \pm 0.06$ \\
\hline Group B & $\begin{array}{c}\begin{array}{c}\text { A } \\
\mathbf{0 . 0} \pm \mathbf{0 . 0}\end{array}\end{array}$ & $\begin{array}{c}\begin{array}{c}\mathbf{A} \\
\mathbf{0 . 0}\end{array} \mathbf{a} \mathbf{0 . 0}\end{array}$ & $\begin{array}{c}\text { A } \\
\mathbf{0 . 0} \pm \mathbf{0 . 0}\end{array}$ \\
\hline & A b & A b & A b \\
\hline Group C & $8.55 \pm 0.04$ & $0.0 \pm 0.0$ & $0.0 \pm 0.0$ \\
\hline & A $\mathbf{a}$ & B $\quad$ b & B $\mathbf{b}$ \\
\hline
\end{tabular}

Value represent mean \pm SE, Group no. $=3$, LSD $=0.1621$,

Different capital letters mean significant $(P<0.05)$ results between periods. Different small letters mean significant $(P<0.05)$ results between groups. Group A (+ve control): infected not treated group; group B (-ve control) not infected-not treated group; group $C$ : Infected with $P$. aeruginosa and treated with pseudomonas aeruginosa-specific bacteriophage intramuscularly with $1.5 \times 107 \mathrm{PFU} / \mathrm{ml}$ once daily for 10 days.

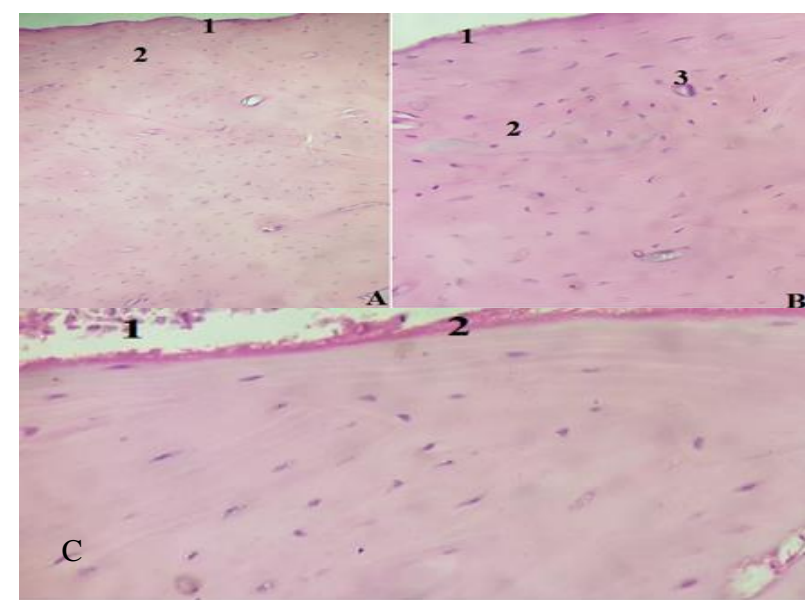

Figure, 2: Normal histology of bone in control group (normal) A: showed normal histological architecture, Periosteum (1), Osteocytes in lacunae (2) $\mathrm{H}$ and E 20x, B: Periosteum (1), Osteocytes in lacunae (2), Haversian canal (3) C: Marrow cavity (1) and endosteum (2), H and E 20x.

At day 7 after inducing infection with $P$. aeruginosa in rabbits, bone section revealed acute osteomyelitis, congestion of blood vessels and the bone marrow is replaced by sever acute inflammatory cell mainly neutrophils with few lymphocytes and macrophages (Fig. 3 and 4). While at day 35 after inducing infection, infected groups showed chronic osteomyelitis represented by sever chronic inflammatory cells infiltrates mainly lymphocytes, and macrophages and hemorrhage between bone trabeculae, also some sections showed extensive fibrosis in the marrow space with MNCs infiltrations mainly lymphocytes, plasma cells and macrophages and between bone trabeculae (Fig. 5 and 6). Treated group (group $\mathrm{C}$ ) with $P$. aeruginosa specific - bacteriophage $\left(1.5 \times 10^{7}\right) \mathrm{PFU} / \mathrm{ml}$ for 10 days showed early repair elucidated by presence whorls of chondrocytes and also presence of multiple osteoblasts indicate bone formation.

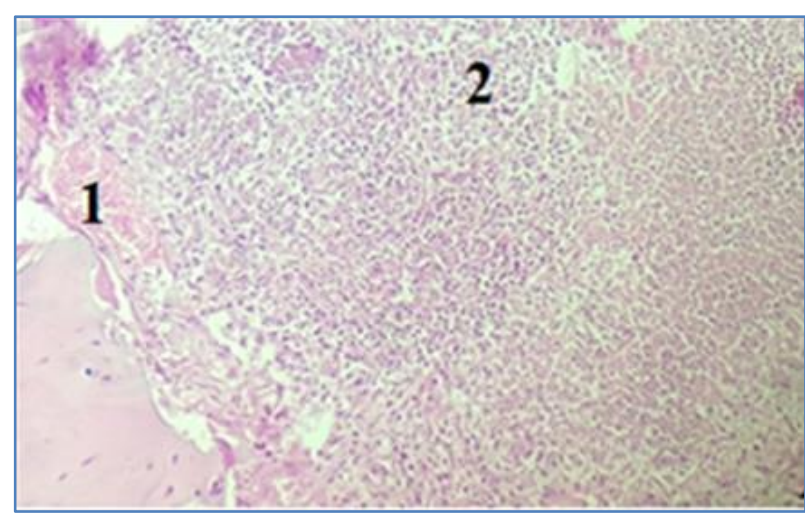

Figure, 3: Histological section of rabbit tibia after 7 days of infection with $P$. aeruginosa shows acute osteomyelitis, congestion of blood vessels( 1 , bone marrow is replaced by sever acute inflammatory cell mainly neurophils with few lymphocytes and macrophages (2), $\mathrm{H}$ and $\mathrm{E} 20 x$.



Figure, 4: Histological section of rabbit tibia after 7 days of infection with $P$. aeruginosa shows acute osteomyelitis, characterized by sever PMNCs infiltration mainly neurophils with few lymphocytes in the bone marrow (1) with osteonecrosis, bone trabecule with empty osteocyte cavities(2), $H$ and $E$ 20x.

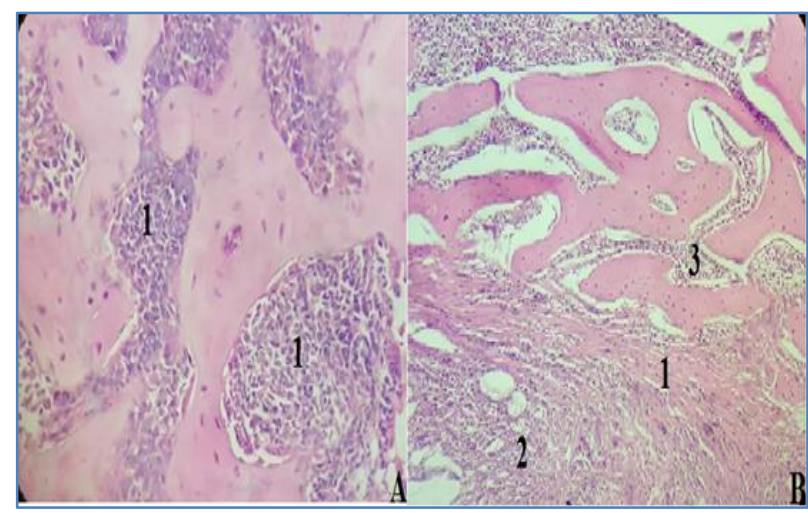

Figure, 5: Histological section of rabbit tibia after 35 days of infection with $P$. aeruginosa shows A: Chronic osteomyelitis, characterized by sever chronic inflammatory cells infiltration mainly lymphocytes, and macrophages and hemorrhage between bone trabeculae (1), B: Chronic osteomyelitis extensive fibrosis in the marrow space (1) with MNCs infiltrations mainly lymphocytes, plasma cells and macrophages (2) and between bone trabeculae (3), $\mathrm{H}$ and $\mathrm{E} 20 x$. 


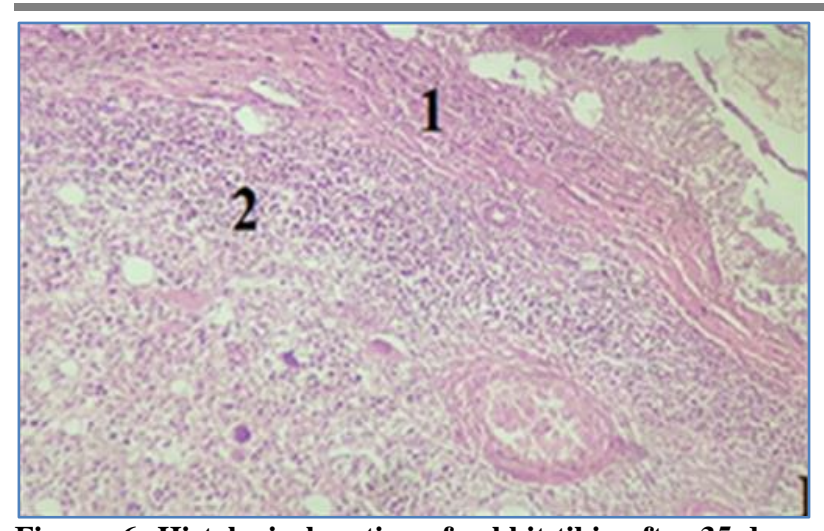

Figure, 6: Histological section of rabbit tibia after 35 days of infection with $P$. aeruginosa shows a chronic osteomyelitis, extensive fibrosis in the marrow (1), with MNCs infiltrations mainly lymphocytes, plasma cells and macrophages with few neurophils (2), $\mathrm{H}$ and $\mathrm{E} 20 \mathrm{x}$.

Also there was extensive fibrosis in the marrow space with present of osteoblasts which indicated bone formation and repair (Fig.7). While bone section of animals left for 10 days after the treatment ended, showed thick granulation tissue formation during bone repair and remodeling. Osteoblasts activity with bone formation and osteoclast activity with bone resorption. The Osteoblasts act as formation or deposition of new bone in one side and multiple multinucleated giant cells resorbing bony trabecula in other side (Fig. 8).

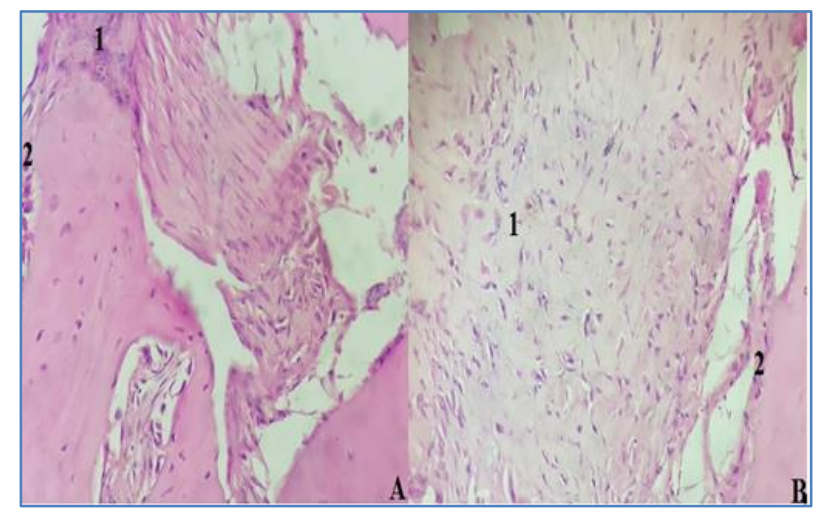

Figure, 7: Histological section of rabbit tibia after 10 days post treatment shows $A$ : early repair in acute inflammation due to presence a cluster of chondrocytes (1), also presence of multiple osteoblasts indicate bone formation (2). B: Extensive fibrosis in the marrow space (1) with present of osteoblasts indicate bone formation and repair (2) $H$ and $E$ 20x.

The pathological finding in rabbit tibia after experimental infection with Pseudomonas aeruginosa gave an evidence of the acute and chronic form of osteomyelitis. These results are in agreement with (25). During acute infection, phagocytes attempt to contain invading microorganisms and, in the process, generate toxic oxygen radicals and release proteolytic enzymes that may lyse the surrounding tissues. Pus resulting from inflammatory response spreads into vascular channels, raising the intraosseous pressure and impairing blood flow. With the progression to a chronic state, the ischemic necrosis of bone results in the separation of devascularized fragments, which were called sequestrum (40).

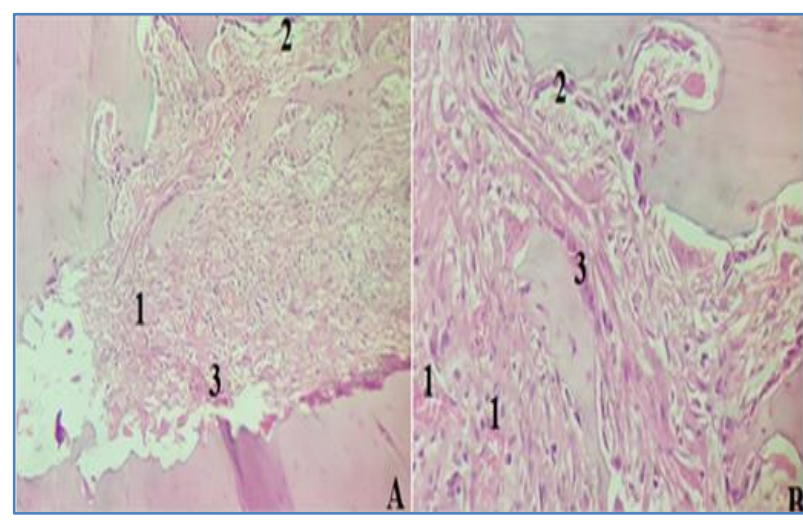

Figure, 8: Histological section of rabbit tibia after 10 days post treatment shows A: Shows A: Thick granulation tissue formation during bone repair and remodeling which separated sequestrum from living bone after chronic osteomyelitis (1). Osteoblasts activity with bone formation (2), osteoclast activity with bone resorption (3). B: Remodeling of bone (1) osteoblasts act as formation or deposition of new bone in one side (2), multiple multinucleated giant cells resorbing bony trabecula in other side (3) $H$ and $E$ 20x.

During the course of infection, bacteria induce local bone destruction (osteolysis). This aids the spread and persistence of infection. An acute infection will cause an intense inflammatory response, thrombosis of endosteal and periosteal vessels, bone infarcts with subsequent abscess and sequestrum formation. A slow, indolent infection will produce a mild to moderate inflammatory response and little or no ischaemic necrosis. A balance will be achieved between bone resorption and new bone formation, and sequestra are less likely to develop. Osteolysis is accomplished by osteoclasts via stimulation by soluble factors such as osteoclast stimulating factor 1 (OSTF1) and macrophage colony-stimulating factor (M-CSF). These in turn are produced by immune system cells after interaction with bacteria (41).

The virulence mechanisms of $P$. aeruginosa are complex and only partially understood. Adherence mediated by pili and other adhesins appears to be important for the colonisation of mucous membranes and other 
surfaces (42), while the production of a mucoid exopolysaccharide matrix that surrounds the cells and anchors them to each other and to the environment is important for growth as a biofilm, in which the bacterial cells are protected from the host innate and immune defences and are overall less susceptible to antibiotics (43). A role for tissue damage and invasion has been recognised for a number of products secreted by $P$. aeruginosa, including elastase, alkaline protease, cytotoxin, phospholipase $\mathrm{C}$ and rhamnolipid. Finally, local and systemic toxicity is most probably related to endotoxin release (44). The management of chronic osteomyelitis typically requires adequate surgical debridement followed by prolonged antibiotic therapy (45).

The recommended duration of systemic antibiotic administration is at least 6 weeks, and patients must take multiple doses daily, creating considerable problems like toxicity and a lack of patient compliance. Furthermore, surgical debridement often creates the problem of bone instability due to dead space formation. This chronic infection may arise either as a complication of acute osteomyelitis or as a result of infection by indolent pathogen. It has been observed that appropriate antibiotics if started in cases of stage-1 osteomyelitis (early acute), may cure the infections (46). However, it becomes difficult to cure higher stage acute and chronic osteomyelitis specially when caused by multidrug resistant bacteria. In addition, biofilm formation and accumulation of dead tissues, e.g. necrotized soft tissues and bone (sequestrum) at the site of infection further aggravates the problem (47). If the causative bacterium is sensitive to a particular antibiotic and proper surgical debridement is ensured, it often fails because of several predictable reasons such as lower concentrations (10-20\%) of antibiotics achieved in bone tissue due to poor vascular perfusion, variation in tissue $\mathrm{pH}$ and oxidative microenvironment interfering with the activity of antibiotics in bone (48).

In contrast to antibiotics, phages are known to penetrate the biofilm as they propagate in their bacterial host. Many phages produce depolymerases that hydrolyze biofilm extracellular polymers and they can penetrate the inner layers of the biofilm by degrading components of the biofilm exopolymeric matrix. There is a report suggesting that the phages can enter the macrophages to kill the intracellular form (49). It is known that there is a decrease in lysis of the bacterial cells when they are in dormant state (50). However, single dose of the phage cocktail has been found to be effective in acute bacterial infection, e.g. septicaemia in mouse burn model caused by Pseudomonas aeruginosa as bacteria actively multiply in blood circulation.

In this research, after treatment with bacteriophage the pathological lesions disappeared and tissues recovered; also the presence whorls of chondrocytes and multiple osteoblasts indicated bone formations. Also in some section extensive fibrosis in the marrow space with present of osteoblasts indicated bone formations and repair. Thick granulation tissue formation during bone repair and remodeling separated sequestrum from living bone after chronic osteomyelitis. Angiogenesis during repair gave an evidence for the remodeling of bone. Osteoblasts act as formation or deposition of new bone in one side and the multiple multinucleated giant cells resorbing bony trabecula in other side. Bone regeneration creates a response in which blood vessels, cells and extracellular matrix are involved. The importance of blood vessels in osteogenesis is known from studies by (51). Following trauma, an inflammatory response and an initial hematoma is produced, with red blood cells, platelets and fibrin. The cells release interleukins and growth factors, setting off the migration of lymphocytes, macrophages, osteoclast precursors and stem cells. These molecular signals promote the differentiation towards endothelial cells, fibroblasts, chondroblasts and osteoblasts, creating a new fibrovascular tissue which replaces the initial coagulate (51).

One phage has shown an ability to effectively diffuse through $P$. aeruginosa EPS matrix and retain an infection potential in the deeper layers of the biofilm by permeating the water channels in the biofilm core (52). This property makes this phage a useful tool in the management of deep infections. 


\section{References}

1. Lew, D.P. and Waldvogel, F.A. (2004). Osteomyelitis. Lancet. 364(9431):369-379.

2. Tice, A.D.; Hoaglund, P.A. and Shoultz, D.A. (2003). Risk factors and treatment outcomes in osteomyelitis. J. Antimicrob. Chemother., 51(5):1261-1268.

3. Eid, A.J. and Berbari, J. (2012). Osteomyelitis: A review of pathophysiology diagnostic modalities and therapeutic options. J. Med. Liban. 60(1):51-60.

4. Tice, A.D.; Hoaglund, P.A. and Shoultz, D.A. (2003). Outcomes of osteomyelitis among patients treated with outpatient parenteral antimicrobial therapy. Am. J. Med. 114(9):723-728.

5. Mcnally, M. and Nagarajah, K. (2010). Osteomyelitis. Orthop. Trauma. 24(6):416429.

6. Lindfors, N.C.; Hyvonen, P.M. Nyyssonen, M.; Kirjavainen, MKankare, J.; Gullichsen, E. and Salo, J. (2010). Bioactive glass S53P4 as bone graft substitute in treatment of osteomyelitis. Bone. 47(2):212-218.

7. Gogia, J.S.; Meehan, J.P; Casare, P.E. and Jamali, A.A. (2009). Local antibiotic therapy in osteomyelitis. Semin. Plast. Surg. 23(2): 100-107.

8. Darley, E.S. and Macgowan, A.P. (2004). Antibiotic treatment of gram-positive bone and joint infections. J. Antimicrob. Chemother. 53(6):928-935.

9. Carvalho, V.C.; Olivera, P.R.; Dal-paz, K.; Depaula, A.P.; Felix, C.S. and Lima, L.L. (2012). Gramnegative osteomyelitis: clinical and microbiological profile. Braz. J. Infect. Dis. 16 (1):63-67.

10. Hancock, R. (1998). Resistance mechanisms in Ps. aeruginosa and other nonfermentative Gram - negative bacteria. Clin. Infect. Dis., 27(1): 93-98.

11. Bonfiglio, G.; Laksai, Y.; Franceschini, N.; Perilli, M.; Segatore, B.; Bianchi, C.; Stefani, S.; Amicosante, G. and Nicoletti, G. (1998) In vitro activity of pipracillin / tazobactam against 615 Ps. aeruginosa strains in intensive care units. Chemother, 44:305-312.

12. Vinodkumar, C.S.; Kalsurmath, S. and Neelagund Y.F. (2008). Utility of lytic bacteriophage in the treatment of multidrugresistant Pseudomonas aeruginosa septicemia in mice. Ind. J. Patholo Microb., 5(3):360-366.

13. Sandeep, K. (2006). Bacteriophage precision drug against bacterial infections. Curr. Sci., 90(5):361-363

14. Kysela, D.T. and Turner, P.E. (2007). Optimal bacteriophage mutation rates for phage therapy. J. Theoret. Biol., 249(3): 411-421.

15. Jassim, S.A.; Abdulamir, A.S. and Abu Bakar, F. (2012). Novel phage-based bio processing of pathogenic E. coli and its biofilms. Wor. J. Microbio. Biotechnol., 28:47-60.

16. Forbes, B.A.; Sahm, D.F. and Weissfeld, A.S. (2010). Bailey and Scott's Diagnostic Microbiology, $12^{\text {th }}$ ed., Pp:1031, MosbyElsevier, at www.elsevierhealth.com.

17. Perilla, M.J.; Ajello, G.; Boop, C.; Elliott, J.; Facklam, R.; Popovic, T. and Wells, J. (2010). Manual for laboratory identification and antimicrobial susceptibility testing of bacterial pathogens of public health importance in developing World. CDC, Atlanta, Georgia, USA.

18. Clinical and Laboratory Standards Institute (CLSI) (2014). Performance standards for antimicrobial susceptibility testing. 20th informational supplement. M 100-S20., Wayne, Pennsylvania; 2014, 30 (1).

19. Clokie, M.R. and Kropinski, A.M. (2008). Bacteriophages: methods and protocols, volume 1: Isolation, characterization and interactions, Humana press, 501:15-21.

20. Pires, D.; Sillankorva S.; Faustino, A. and Azeredo, J. (2011). Use of newly isolated phages for control of Pseudomonas aeruginosa PAO1 and ATCC 10145 biofilms. Res in Microb., 162 (8):798-806.

21. Knezevic, P. and Petrovic, O. (2008). A colorimetric microtiter plate method for assessment of phage effect on Pseudomonas aeruginosa biofilm. J. Microbiol. Meth., 74(2 3):114 118.

22. Budzik, J.M.; Rosche, W.A.; Rietsch, A. and O'Toole, G.A. (2004). Isolation and characterization of generalized transducing phage for Pseudomonas aeruginosa strains PAO1 and PA14. J. Bacteriol., 186:32703273.

23. Nuh, K. (2004). A Comparison between Medetomidine-Ketamine and Xylazine- 
Ketamine Anaesthesia in Rabbits. Turk J. Vet. Anim. Sci., 28:921-926.

24. El-Kamel, A.H. and Baddour M.M. (2007). Gatifloxacin biodegradable implant for treatment of experimental osteomyelitis: in vitro and in vivo evaluation. Drug Deliv. 14(6):349-356.

25. Kanellakopoulou, K.; George, C.T.; Maria, K.; Ismini, D.; Lydia, N.; Eleftherios, D.; Evangelos, J. G-B. Andreas, A.; Panayotis, K.; and Helen, G. (2008). Local Treatment of Experimental Pseudomonas aeruginosa Osteomyelitis with a biodegradable dilactide polymer releasing ciprofloxacin. Antimicrob Agent Chemother., 52(7):2335-2339.

26. Martinez, A.; Guitián, F.; López-Píriz, R.; Bartolomé, J.F.; Cabal, B.; Esteban-Tejeda, L.; Ramón, T. and José, S.M. (2014) .Bone loss at implant with titanium abutments coated by soda lime glass containing silver nanoparticles: A histological study in the dog. PLoS ONE. 9(1):86-92.

27. SAS. (2012). Statistical Analysis System, User's Guide. Statistical. Version 9.1 ${ }^{\text {th }}$ ed. SAS. Inst. Inc. Cary. N.C. USA.

28. American Thoracic Society (2005). Infectious Diseases Society of America Guidelines for the management of adults with hospital-acquired, ventilatorassociated, and healthcare-associated pneumonia. Am. J. Respir. Crit. Care Med., 171:388- 416.

29. Valerie, A.; Shiri, N-V.; Yardena, S-I.; Shaltiel, C. and Yehuda C. (2006). Multidrug Resistant Pseudomonas aeruginosa: Risk Factors and Clinical Impact. Antmicrob. Age and Chemother., 50(1):43-48

30. Chaudry, I.H. and Ayala, A. (1993). Mechanism of increased susceptibility to infection following burn. Am. J. Surg. 165: 595-675.

31. Savaş, L.; Duran, N.; Savaş, N.; Önlen Y. and Ocak S. (2005). The prevalence and resistance patterns of $P$. aeruginosa in intensive care units in a University hospital, Turkish J. Med. Sci., 35:317-322.

32. Nadeem, S.G.; Qasmi, S.A.; Afaque, F.; Saleem, M. and Hakim S.T. (2009). Comparison of the in-vitro susceptibility of clinical isolates of $P$. aeruginosa in a local hospital setting in Karachi, Pakistan. BJMP, 2(4):35-39.

33. Gad, G.F.; El-Domany, R.A.; Zaki, S. and Ashour, H.M. (2007). Characterization of $P$. aeruginosa isolated from clinical and environmental samples in Minia, Egypt: prevalence, antibiogram and resistance mechanisms, J. Antimicrob. Chemother., 60 (5):1010-1017.

34. Hancock, R.W.; Lehrer, R. (1998). Cationic peptides: a new source of antibiotics. Trends Biotechnol., 7:167-174.

35. Dalhoff, A. (1994). Quinolone resistance in P. aeruginosa and Staphylococcus aureus Development during therapy and clinical significance. Infect. 22(2):111-121.

36. Neu, H.C. (1992). The crisis in antibiotic resistance, Sci., 257:1064-1073.

37. Pai, H.; Kim, T.W.; Kim, J.; Lee, J.H.; Choe, K.W. and Gotoh N. (2001). Carbapenem resistance mechanisms in $\mathrm{P}$. aeruginosa clinical isolates. Antimicrob. Agents Chemother., Pp: 480-484.

38. Vojtová, V.; Kolár, M.; Hricová, K.; Uvízl, R.; Neiser, J. Blahut, L. and Urbánek, K. (2011). Antibiotic utilization and $P$. aeruginosa resistance in intensive care units new microbiologic, 34:291-298.

39. Zahra, Z.; Umar, S.; Aqsa, K. and Waqas, N. (2014). Isolation and partial characterization of virulent phage specific against Pseudomonas aeruginosa. Global J. Med. Res. Microb. and Path., 14(1) Version 1.0 Year 2014.

40. Lew, D.P. and Waldvogel, F.A. (1997). Osteomyelitis: Current concepts. N. Engl. J. Med., 336(14):999-1007.

41. Dewhirst, F. (1982). N-Acetyl muramyl dipeptide stimulation of bone resorption in tissue culture. Infect. Immun., 35:133-137.

42. Doig, P.; Todd, T. Sastry, P.A. (1988). Role of pili in adhesion of Pseudomonas aeruginosa to human respiratory epithelial cells. Infect. Immun., 56:1641-1646.

43. Drenkard, E. and Ausubel, F.M. (2002). Pseudomonas biofilm formation and antibiotic resistance are linked to phenotypic variation. Nature; 416:740-743.

44. Pollack, M. (1983). The role of exotoxin A in Pseudomonas disease and immunity. Rev. Infect. Dis., 5(5):979-984. 
45. Mader, J.T.; Shirtliff, M.E.; Bergquist, S.C. and Calhoun J. (1999). Kanellak-Opoulou et al. Antimicrob. Agents Chemother. http://aac. asm.org/ on June 13, 2017 by guest Antimicrobial treatment of chronic osteomyelitis. Clin. Orthop. 360:47-65.

46. Wills, Q.F.; Kerrigan, C. and Soothill, J.S. (2005). Experimental bacteriophage protection against Staphylococcus aureus abscesses in a rabbit model. Antimicrob. Agents and Chemother., 49:1220-1221.

47. Brady, R.A.; Leid, J.G.; Calhoun, J.H.; Costerton, J.W. and Shirtliff M.E. (2008). Osteomyelitis and the role of biofilms in chronic infection. FEMS Immunol. Med. Microbiol., 52(1):13-22.

48. Lazzarini, L.; Lipsky, B.A. and Mader, J.T. (2005). Antibiotic treatment of Osteomyelitis: What have we learned from 30 years of clinical trials? Int. J. Infect. Dis., 9:127-138.
49. Broxmeyer, L.; Sosnowska, D.; Miltner, E.; Chacón, O.; Wagner, D. and McGarvey, J. (2002). Killing of Mycobacterium avium and Mycobacterium tuberculosis by a mycobacteriophage delivered by a nonvirulent Mycobacterium: a model for phage therapy of intracellular bacterial pathogens. J. Infect. Dis., 186(8):1155-1160.

50. Matsuzaki, S.; Rashel, M.; Uchiyma J.; Ujihara, T.; Kuroda, M.; Ikeuchi M.; Fujieda, M.; Wakiguchi, J. and Imai, S. (2005). Bacteriophage therapy: A revitalized therapy against bacterial infectious diseases. J. Infect. Chemother., 11(5):211-219.

51. Trueta, J. (1963). The role of blood vessels in osteogenesis. J. Bone Joint Surg. Br., Pp:45:402.

52. Sutherland, I.W.; Hughes, K.A.; Skillman, L.C. and Tait, K. (2004). The interaction of phage and biofilms. FEMS Microbiol. Lett., 232:1-6.

\section{فعالية العاثي المعزول في علاج التهاب العظم المزمن والمستحدث تجريبياً بواسطة الزوائف الزنجارية

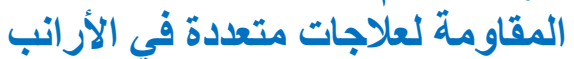

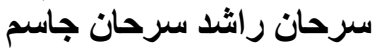$$
\text { فرع الفسلجة و الأدوية، كلية الطب البيطري، جامعة و اسط، العراق. }
$$ \\ E-mail: srashid@uowasit.edu.iq \\ الخخلاصة}

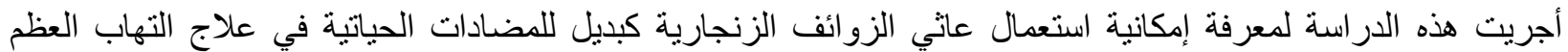

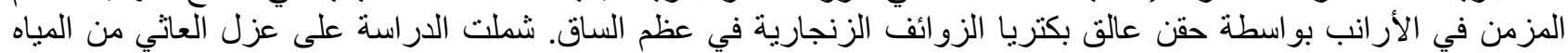

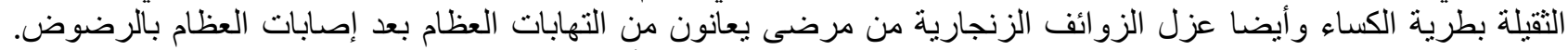

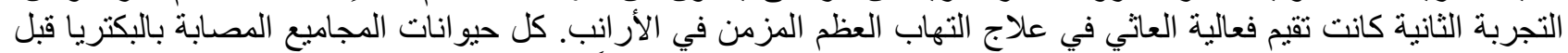

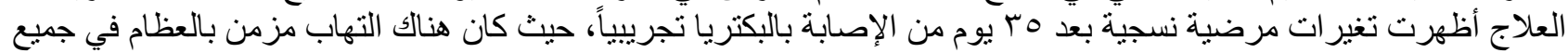

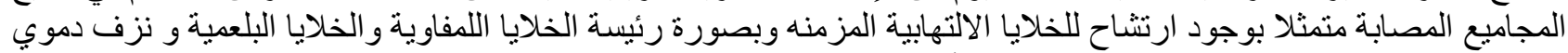

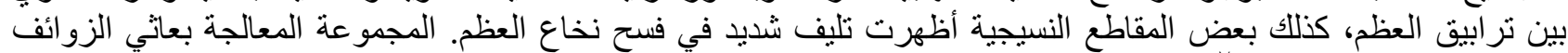

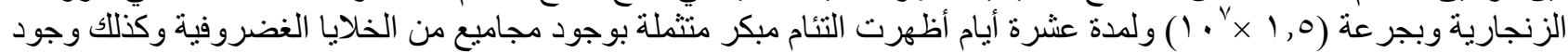

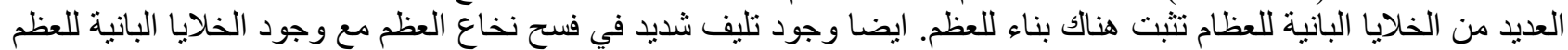

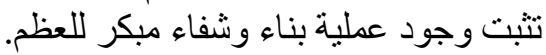

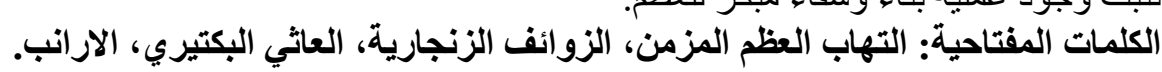

